\title{
STRATEGI PENCEGAHAN BAHAYA KONTEN RADIKAL DAN PORNOGRAFI DI INTERNET
}

\author{
Nurdin Nurdin \\ Muhammad Nur Ahsan \\ Institut Agama Islam Negeri (IAIN) Palu \\ Email: nnurdin@iainpalu.ac.id \\ nnurdin69@gmail.com
}

Abstract :

Internet does not only provide positive information but also depict negative information and images such as radical and pronography. Previous studies found that most of young citizens have accessed online radical and pornography contents. This caused massive impacts on their behaviour and society life. Instead the negative impacts have been addressed in previous studies, little is known how those impacts should be eliminated. Through an intensive literature review approach, this study, therefore, is intended to provide insight on how the impacts of online radicalism and pornography should be prevented or eliminated. The author usd secondary data from various online data sources such as journals, mass media sites, and other relevant sites. The results show that online radical contents can trigger society to be radical and lack toleran toward social life. Meanwhile, online pronography contents cause young generation to lack sensitive toward their marriage life and cause them to practice abnormal sexual life. This study also found that the impacts can be prevented and eliminated through increasing Muslim leaders and da'i roles in spreading intensive Islamic values into society, increassing government actor roles to monitor and block such contents, and providing training for society to block negative sites on their own. In conclusion, online radical and pornography contents can impact society life regarding increasing violent and intolerant behaviour, while online pornography contents can cause lack 
Nurdin \& Mohammad Nur Ahsan, Strategi Pencegahan Bahaya...

sexual sensitivity and increase violent toward women. However, such impacts can be prevented and eliminated through increasing da'i roles, incresing government actor roles in monitoring the sites, and improving citizen skills to block the sites.

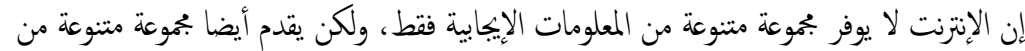

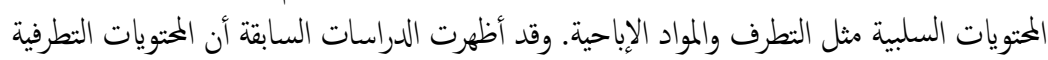

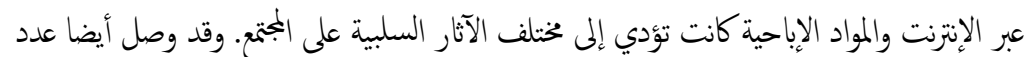

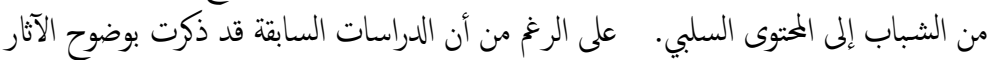

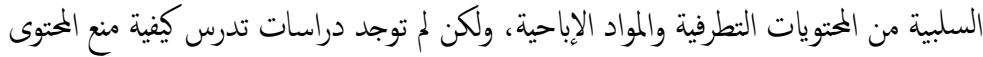

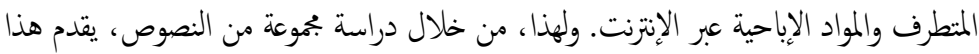

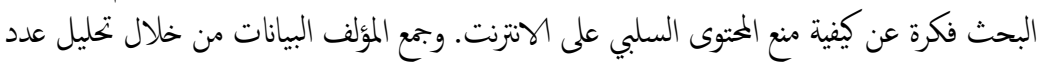

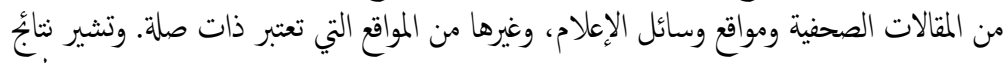

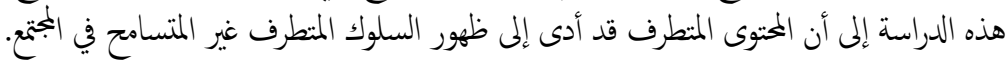

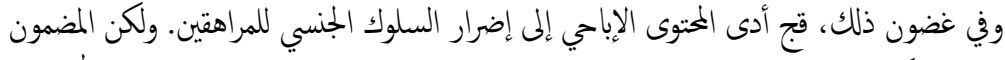

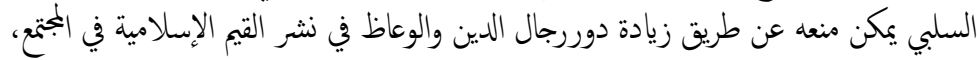

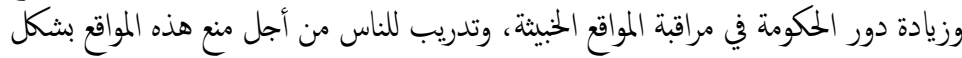

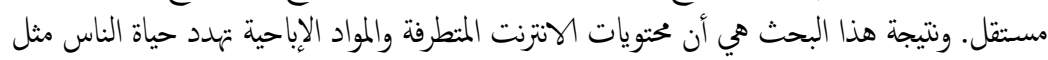

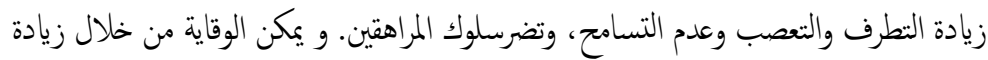

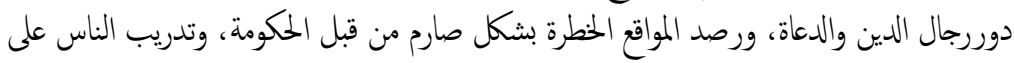

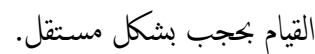

Kata Kunci: radikalisme online, pornografi online, dampak, strategi pencegahan.

\section{Latar Belakang}

Indonesia sebagai negara dengan populasi Muslim terbesar di dunia memiliki pengguna internet yang sangat banyak. Data terbaru dari Asia World Stats menunjukkan bahwa pengguna Internet saat ini berjumlah 78 
juta orang atau sekitar $30.5 \%$ dari jumlah penduduk Indonesia ${ }^{1}$. Dalam beberapa tahun kedepan, pengguna Internet di indonesia akan terus meningkat dengan tajam. Hasil penelitian yang dilakukan oleh UNICEF menemukan bahwa jumlah pengguna Internet di kalangan anak-anak dan remaja berjumlah sekitar 30 juta orang ${ }^{2}$. Anak - anak dan remaja tersebut menggunakan Internet untuk mengakses berbagai situs baik websites, social media, dan situs-situs lainya. Menurut Asosiasi Pengguna Internet Indonesia (APJII) usia remaja ini memiliki karakter yang sangat aktif menggunakan jejaring tehnologi digital dan memiliki kecakapan dalam mengoperasikan teknologi berbasis internet ${ }^{3}$.

Situs-situs yang dibuat di Internet umumnya untuk keperluan baik yaitu meningkatkan taraf hidup manusia untuk berbagai keperluan baik ekonomi, sosial, budaya, informasi, politik, dan lain-lain. Namun ada juga sejumlah situs yang dianggap berkonten negative seperti berisi kontent radikal dan pornografi. Jumlah situs radikal dan porno di Indonesia saat ini semakin berkembang pesat ${ }^{4}$. Sampai saat ini Departement Komunikasi

${ }^{1}$ InternetWorldStats. (2015). Internet Users in Asia. Retrieved 20 januari 2016, from Internet World Stats http://www.internetworldstats.com/stats3.htm\#asia

${ }^{2}$ Kominfo. (2014). Siaran Pers Tentang Riset Kominfo dan UNICEF Mengenai Perilaku Anak dan Remaja Dalam Menggunakan Internet Retrieved 03 Maret 2016, from Kominfo http://kominfo.go.id/index.php/content/detail/3834/Siaran+Pers+No. +17-PIHKOMINFO-2-

2014+tentang +Riset + Kominfo + dan $+\mathrm{UNICEF}+$ Mengenai + Perilaku + Anak + dan + Rema ja +Dalam+Menggunakan +Internet $+/ 0 /$ siaran pers\#.VtesV0AaiwY

3 APJII. (2014). Profil Pengguna Internet Indonesia 2014. Jakarta: Asosiasi Penyedia Jasa Internet Indonesia (APJII).

${ }^{4}$ Saifuddin, L. H. (2016). Menag: Situs Radikal di Indonesia Berkembang Pesat. Retrieved 3 Maret 2016, from Solopos 
Nurdin \& Mohammad Nur Ahsan, Strategi Pencegahan Bahaya...

dan Informasi (Depkominfo) sudah memblokir sekitar 814594 situs radikal dan pornografi ${ }^{5}$, namun jumlah situs yang belum terdeteksi masih sangat banyak. Belum lagi situs situs yang dibuat individu yang memposting konten-kontent radikal dan pronografi.

Ancaman bahaya terpaparnya remaja terhadap pornografi dan radikalisme semakin nyata dengan semakin menyebarnya penggunaan Internet diberbagai daerah seperti sekolah-sekolah. Situs-situs pornografi dan radikalisme tumbuh menjamur baik yang berada dalam maupun luar negeri. Meskipun Depkominfo telah melakukan proses pemblokiran, namun situs-situs semacam itu di buat setiap hari baik oleh kelompok tertentu maupun individu. Hasil penelitian yang dilakukan Komisi Perlindungan Anak Indonesia (KPAI) terhadap 4.500 pelajar SMP dan SMA di 12 kota besar Indonesia menunjukkan hasil yang cukup mencengangkan. Sebanyak 97 persen responden mengaku telah mengakses situs berkonten pornografi dan juga menonton video porno melalui internet ${ }^{6}$.

Jumlah situs yang menyajikan konten-konten radikal di Internet terus bertambah setiap hari. Data tahun 2015 dari Depkominfo menunjukkan bahwa sekitar 766.394 situs internet telah ditutup baik yang

\footnotetext{
${ }^{5}$ Kominfo. (2015). Kominfo Sudah Blokir 814.594 Situs Radikal Retrieved 21

Pebruari 2016, from Kominfo http://kominfo.go.id/index.php/content/detail/5083/Kominfo+Sudah+Blokir+814.594+Sit us+Radikal+/0/sorotan media\#.Vsm0q0AaiwY

6 KPAI. (2014). Survei: 97\% Remaja Indonesia Mengakses Situs Porno. Retrieved 03 Maret 2016, from Okezone http://techno.okezone.com/read/2013/09/24/55/870832/survei-97-remaja-indonesiamengakses-situs-porno
} 
terkait radikal maupun pornografi ${ }^{7}$. Namun jumlah situs porno dan radikal yang ada masih sangat banyak yang belum terlacak karena ketika suatu situs yang ditutup, maka akan dibuat lagi situs baru yang berbeda namun memiliki konten yang sama. Kemudian juga terdapat situs-situs pribadi yang setiap hari di manfaatkan untuk menyebar konten pornografi dan radikal. Sementara pemerintah biasanya melakukan pemblokiran secara berkala bukan setiap saat.

Untuk itu diperlukan usaha-usaha untuk mencegah dan menghindarkan masyarakat dari akses terhadap situs-situs tersebut negative tersebut. Selama ini sudah banyak pihak-pihak terkait yang melakukan sosialisasi baik secara formal maupun informal terkait caracara mencegah akses terhadap situs-situs tersebut. Tetapi belum banyak menulis dijurnal ilmiah terkait bagaimana sebaiknya mencegah bahaya situs-situs radikal dan porno tersebut. Untuk itu tulisan ini bermaksud membahas bagaimana strategi mencegah terpaparnya masyarakat terhadap situs-situs negative tersebut. Tujuan dari tulisan ini adalah untuk meningkatkan pemahaman dan pengetahuan masyarkat terhadap bahaya konten radikal dan pornografi di Internet dan cara pencegahannya.

Untuk mencapai tujuan tersebut maka tulisan ini akan menjawab pertanyaan sebagai berikut: Apa bahaya situs-situs radikal dan pornografi terhadap masyarakat, dan bagaimana cara pencegahannya?

\footnotetext{
${ }^{7}$ Wicaksono, K., \& Haryanto, A. T. (2016). Ratusan Ribu Situs Diblokir Sepanjang 2015. Retrieved 03 Maret 2016, from VIVA http://teknologi.news.viva.co.id/news/read/718117-ratusan-ribu-situs-diblokir-sepanjang$\underline{2015}$
} 
Nurdin \& Mohammad Nur Ahsan, Strategi Pencegahan Bahaya...

Paper ini ditulis dengan struktur sebagai berikut; setelah bagian latarbelakang ini maka dibagian kedua akan disajikan tinjuan pustaka terkait beberapa istilah penting dalam tulisan ini. Pada bagian ketiga akan dibahas pendekatan yang digunakan dalam menulis paper ini. Hasil dan pembahasan paper ini akan disajikan di bagian ke-empat. Sedangkan kesimpulan dan keterbatasan tulisan ini akan disajikan di bagian ke lima dan terakhir dari tulisan ini.

\section{Kajian Pustaka}

Bagian ini membahas beberapa teori terkait beberapa istilah utama yang menjadi kajian tulisan ini. Beberapa poin utama yang dibahas dalam bagian tinjauan pustaka ini antara lain pengertian Internet, pengertian radikalisme, dan pengertian pornografi. Tujuannya adalah untuk memberi pemahaman mendasar terhadap topik tulisan ini sebelum dilakukan pembahasan lebih lanjut di bagian pembahasan.

\section{a. Pengertian Internet}

World wide web generasi pertama dibuat sekitar tahun 1990an di sebuah laboratorium di Jenewa Swiss oleh Tim Berners-Lee dan tim penelitinya. Tujuannya adalah untuk membantu transformasi dalam bidang politik, ekonomi, dan sosial diseluruh dunia ${ }^{8}$. Istilah World Wide Web (bisanya disebut dengan "Web" saja) adalah bagian yang paling penting dari beroperasinya Internet. Web didefinsikan sebagai suatu sistim teknologi sosial untuk menghubungkan manusia dengan menggunakan

\footnotetext{
${ }^{8}$ Krotoski, A. 2010. The internet's cyber radicals: heroes of the web changing the world Retrieved 20 Pebruary 2016, from The Guardian http://www.theguardian.com/technology/2010/nov/28/internet-radicals-world-wide-web
} 
suatu jaringan teknologi ${ }^{9}$. Sejak pertama dibuat, Internet telah berkembang begitu pesat seperti yang kita alami saat ini.

Kalau pada Internet generasi pertama manusia hanya dapat membaca konten tulisan saja, maka pada Internet generasi sekarang manusia bukan hanya dapat membaca konten tapi juga sudah bisa saling berkomunikasi, berbagi, dan mengirim berbagai konten secara aktif. Akibtanya generasi baru Internet saat ini telah melahirkan berbagai sarana komunikatif seperti e-mail dan berbagai aplikasi media sosial. Berbagai aplikasi tersebut telah memebantu manusia terhubung dengan manusia lain diberbagai belahan dunia melalui suatu alam maya (virtua space). Akibatnya manusia tidak terlalu tergantung lagi pada model pertemuan tatap muka.

Internet sudah dimanfaatkan untuk berbagai keperluan dalam kehidupan manusia dewasa ini. Internet sudah dimanfaatkan untuk menfasilitasi hubungan sosial melalui saluran komunikasi secara online seperti email dan media sosial. Berbagai aplikasi di Internet tersebut dianggap bermanfaat dalam menghubungkan manusia untuk meningkatkan kepuasan hidup ${ }^{10},{ }^{11}$. McKenna dkk., ${ }^{12}$ mengatakan bahwa ketika manusia memulai berkomunikasi lewat Internet, maka akan besar

${ }^{9}$ Aghaei, et al.,. Evolution of the World Wide Web, P.1

${ }^{10}$ McKenna, K. Y. A., Green, A. S., \& Gleason, M. E. J. (2002). Relationship Formation on the Internet: What's the Big Attraction? Journal of Social Issues, Vol. 58 No. 1, 2002, pp. 9-31.

${ }^{11}$ Ellison, N. B., Steinfield, C., \& Lampe, C. (2007). The Benefits of Facebook "Friends:" Social Capital and College Students' Use of Online Social Network Sites. Journal of Computer-Mediated Communication, Vol. 12 No. 4, 2007, pp. 1143-1168.

${ }^{12}$ McKenna, et al., Relationship Formation on the Internet, p.11 
Nurdin \& Mohammad Nur Ahsan, Strategi Pencegahan Bahaya...

kemungkinan dia akan membangun hubungan sosial yang lebih dekat pada tahap selanjutnya. Fenomena ini sering dimanfaatkan oleh orangorang atau kelompok radikal untuk memulia suatu hubungan lewat Internet, yang kemudian ditindak lanjuti secara lebih mendalam lewat pertemuan secara konvensional.

b. Pengertian Radikalisme

Radikalisme terdapat dalam berbagai masyarakat dan agama di dunia ini. Radikalisme itu sendiri sering dipahami sebagai suatu situsi atau perilaku yang dianggap berbeda dan menyimpang dengan nilai-universal yang dipercaya oleh masyarakat pada umumnya. Max Weber mengatakan bahwa radikalisme merupakan suatu aspek perbedaan krusial yang menyimpang dari kepercayaan umum $^{13}$. Radikalisme itu bukan hanya ada dalam masyarakat Muslim tetapi juga terdapat dalam komunitas masyarakat dan agama lainnya seperti Kristen ${ }^{14}$ dan Yahudi ${ }^{15}$.

Istilah radikalisme itu sendiri belum ada definisi yang tepat dan para pakar mendefinsikannya sesuai dengan konteks dan pandangan mereka sendiri. Istilah radikalisme sebenarnya berasal dari kata Latin radix yang berarti "root" atau "akar" yang berarti sesuatu yang berasal dari dasar. Dalam konteks politik, istilah radikalisme didefinisikan sebagai "pendekatan mendasar terhadap politik yang maksudnya bahwa pihak-

13 Bittner, E. (1963). Radicalism and the Organization of Radical Movements. American Sociological Review, 28(6), 928-940

${ }^{14}$ Fleet, M. (1992). Christian Communities in Chile and Peru Toronto, Kellog Institute, 2002, p.3

${ }^{15}$ Shahak, I. and N. Mezvinsky (1999). Jewish Fundamentalism in Israel. Bon Germany, Pluto Press. 
pihak yang berpandangan radikal lebih menginginkan perubahan mendadak ketimbang perubahan pelan-pelan ${ }^{16},{ }^{17}$.

Sementara itu kata radikalisme dalam konteks Islam sering dipahami sebagai suatu pemahaman yang didasari pada interpretasi nilai-nilai Islam yang keras terutama adanya kepercayaan tentang perllunya suatu negara Islam global dengan penerapan hukum Islam atau Syariah Islam $^{18}$. Kata radikalisme dalam Islam juga sering dikaitkan dengan kata "jihad". Kata "Jihad" merupakan kata benda yang berasal dari bahasa Arab yaitu kata benda tiga suku kata "jahada", yang secara literal berarti "melakukan jihad" (to do jihad). Akar dari kata "jihad" juga dikaitkan dengan konsep "berjuang" (striving) atau melakukan perjuangan (to strive) $)^{19}$. Meskipun kata "jihad" sebenarnya tidak ada hubungannya dengan aksi kekerasan dan perang, namun kata "jihad" sering dikaitkan dengan istilah teror dan radikalisme $e^{20},{ }^{21}$.

c. Pengertian Pornografi

${ }^{16}$ University-of-Aberdeen. 2014. Understanding Radicalism. Retrieved 30 June 2015, from University of Aberdeen https:/www.abdn.ac.uk/radicalism/understanding.shtml

${ }^{17}$ Nurdin, N. (2016). Radicalism on Worl Wide Web and Propaganda Strategy Al-Ulum, 16(2)

${ }^{18}$ Mauro, R. 2014. Understanding Islamic Extremism. Retrieved 24 June 2015, from The Clarion Project http://www.clarionproject.org/understanding-islamism/islamicextremism\#, p.1

${ }^{19}$ Ramsay, G., Jihadi Culture on the World Wide Web. New York: Bloomsbury Publishing, 2013, p.3

${ }^{20}$ Ridouani, D, The Representation of Arabs and Muslims in Western Media. RUTA, 3, 15. 2011, p.3

${ }^{21}$ Nurdin, N. (2016). Radicalism on Worl Wide Web... 
Nurdin \& Mohammad Nur Ahsan, Strategi Pencegahan Bahaya...

Sebenarnya tidak ada definisi pornnografi yang baku yang diberikan oleh para ahli. Masing-masing daerah dan negara memiliki pengertian pornografi tersendiri. Menurut Rea, pornografi itu dapt digolongkan dalam dua kategori yaitu "soft core" dan "hardcore". Softcore pronografi dianggap pronografi yang memperlihatkan bagianbagian tubuh yang sensitif dan kata vulgar tentang seks. Sementara "hardcore" pornografi merupakan konten pornogafi yang mempelihat kan kegiatan "persetubuhan" dan "alat kelamin" diberbagai media ${ }^{22}$.

Kata pornografi berasal dari bahasa Yunani "porne" yang berarti "sundal", dan "graphein" yang berarti "menulis"23. National Coalition menyebut pornografi sebagai "bahan yang mengandung unsur seks secara explicit"'24. Jadi pornografi dapat didefinisikan sebagai usaha memperlihatkan bahan-bahan yang mengandung unsur-unsur seks baik yang berupa gambar maupun tulisan kepada publik.

Dalam kamus besar bahasa Indonesia, pornografi didefinsikan sebagai usaha penggambaran tingkah laku secara erotis dengan lukisan atau tulisan untuk membangkitkan nafsu birahi ${ }^{25}$. Sedangkan dalam konteks penyajian pornografi di berbagai situs Internet, maka pornografi Inc.

${ }^{22}$ Rea, M. C. (2001). What is pornography? Malden, USA: Blackwell Publisher,

${ }^{23}$ Malamuth, N. M. (1999). Pornography Encyclopedia of Violence, Peace, and Conflict, Volume (Vol. 3, pp. 14). Los Angeles.

${ }^{24}$ National-Coalition. (2011). FACTS FOR PREVENTION: The Impact of Pornography on Children \& Youth. Retrieved 05 Maret 2016, from National Coalition to Prevent http://www.preventtogether.org/Resources/Documents/Impact_of_Porn_on_Youth_9.pdf.

${ }^{25}$ KBI. (Ed.) (1999). Jakarta: Balai Pustaka 
di anggap sebagai penyajian situs-situs terlarang yang menggambarkan perilaku dan praktik seksual ${ }^{26}$.

\section{Pendekatan Tulisan}

Dalam menulis paper ini, penulis menggunakan pendekatan kajian pustaka dimana data dikumpul dari berbagai literatur sekunder. Dengan kata lain, penulis hanya menggunakan data sekunder melalui kajian pustaka yang mendalam terhadap berbagai literature online dalam bidang radikalisme dan pornografi di Internet. Kemudian terkait bahaya konten pornografi dan radikalisme dan juga strategi pencegahannya, penulis juga mengkaji berbagai literature ilmiah yang ada di Internet. Pendekatan ini dilakukan dengan cara mengakaji berbagai literature yang sudah ada guna melahirkan ide-ide baru untuk dimanfaatkan dimasa mendatang ${ }^{27}$. Dalam melakukan analisis, penulis menggunakan pendekatan "thematic" atau "conceptual categories" dimana hasil kajian berbagai referensi di organisasikan menurut topik atau issue ${ }^{28}$ yang diteliti oleh penulis. Dalam hal ini, berbagai isu pornografi dan radikalisme beserta startegi pencegahannya yang ditemukan dalam literatur terdahulu selanjutnya di analisa dan dibahasa dalam tulisan ini. Mskipun tulisan ini

${ }^{26}$ Owens, E. W., Behun, R. J., Manning, J. C., \& Reid, R. C. (2012). The Impact of Internet Pornography on Adolescents: A Review of the Research. Sexual Addiction \& Compulsivity, 19, P. 103.

${ }^{27}$ Webster, J., \& Watson, R. T. (2002). Analyzing the Past to Prepare for the Future: Writing a Literature Review. MIS Quarterly, 26(2), 10.

${ }^{28}$ Labaree, R, Organizing Your Social Sciences Research Paper: The Literature

Review. Retrieved 22 Oktober 2015, from USC Libraries http://libguides.usc.edu/c.php?g=235034\&p=1559822 (2013) 
Nurdin \& Mohammad Nur Ahsan, Strategi Pencegahan Bahaya...

menggunakan pendekatan tinjauan pustaka semata, penulis tetap harus menjelaskan metodology analisis ${ }^{29}$.

\section{Pembahasan}

Hasil kajian terhadap berbagai literature terkait bahaya radikalisme dan pornografi di Internet dan juga strategi pencegahannya dibahas dalam bagian ini. Pembahasan dimulai dengan penyajian bahaya radikalisme dan pornografi di Internet. Kemudian di ikuti dengan pembahsan strategi pencegahan bahaya konten radikal dan pornografi tersebut.

a. Bahaya radikalisme di Internet

Konsep radikalisme sebenarnya sudah mulai ada semenjak jaman dahulu karena radikalisme itu sendiri merupakan tindakan yang berbentuk kekerasan baik fisik maupun gagasan. Pikiran radikal yang menganggap gagasan suatu kelompok lebih benar dari kelompok lainnya telah melahirkan berbagai tindakan kekerasan yang menyebabkan kematian dan kerusakan yang begitu parah dimuka bumi. Semenjak jaman nabinabi dan kerajaan telah ada pikiran-pikiran dan tindakan radikal di tengah-tengah masyarakat. Namun bentuk dan strategi saja yang berbeda dengan yang terjadi dewasa ini.

Di zaman moderen ini aktiftas radikalisme dilakukan secara lebih terorganisir yang melibatkan sarana teknologi informasi dan komunikasi.

${ }^{29}$ Levy, Y., \& Ellis, T. J, A Systems Approach to Conduct an Effective Literature Review in Support of Information Systems Research. Informing Science, (2006) Vol.9, p. 181-212 
Kelompok-kelompok radikal juga telah mengunakan strategi manajemen moderen dalam operasi mereka baik untuk merekrut anggota maupun penggalangan dana. Akibatnya tindakan mereka telah menyebabkan kerusakan yang lebih luas dibandingkan dengan tindakan radikalisme yang terjadi dijaman dahulu. Kelompok radikal juga melibatkan diri dalam banyak tindakkan politik radikal yang telah menyebabkan kematian ratusan juta jiwa dan membinaskan harta-benda diberbagai belahan dunia seperti Afganistan, Iraq, Iran, Libia, Suria dan Yaman.

Meskipun konteks radikalisme dipahami berbeda-beda diberbagai negera, tetapi sejumlah ahli sepakat bahwa radikalisme itu bersumber dari interpretasi secara radikal terhadap ajaran - ajaran Islam dan interpretasi yang tajam tersebut lahir dari individu dan kelompok yang berasal dari aliran Islam tertentu saja ${ }^{30}$. Meskipun jumlah individu dan kelompok radikal itu sedikit, tapi kehadiran mereka dapat membawa dampak yang sangat nyata terhadap masyarakat dan pemerintahan terutama setelah aktifitas radikalisme sudah mulai pindah ke dunia maya atau Internet. Akibatnya, perlu adanya usaha nyata dari berbagai pihak untuk memonitor aktifitas radikal tersebut.

Dalam kaintannya dengan radikalieme di dunia maya, kaum jihadis telah membuat sejumlh situs radikal untuk kepentingan penyebaran ideologi mereka. Sebuah situs radikal di Internet biasanya menyajikan pesan-pesan yang antara lain:

1. Ingin melakukan perubahan dengan cepat menggunakan kekerasan dengan mengatasnamakan agama

${ }^{30}$ Mauro, R. (2014). Understanding Islamic Extremism. Retrieved 24 June 2015, from The Clarion Project http://www.clarionproject.org/understanding-islamism/islamicextremism\# 
Nurdin \& Mohammad Nur Ahsan, Strategi Pencegahan Bahaya...

2. Takfiri atau mengkafirkan orang lain.

3. Mendukung, menyebarkan, dan mengajak bergabung dengan ISIS/IS

4. Memaknai jihad secara terbatas ${ }^{31}$

Agus SB yang merupakan salah satu pejabat Badan Nasional Penanggulangan Terorisme bahkan menyatakan bahwa tren munculnya bibit terorisme baru-baru ini karena banyak yang belajar agama dari internet yang jumlahnya sekitar $47 \%$ orang belajar agama dari internet ${ }^{32}$. Radikalisme di Internet juga membahayakan remaja dengan cara merayu remaja untuk masuk jaringan mereka. Disamping itu juga kaum radikalisme di Internet kadang-kadang menyediakan berbagai informasi yang sangat berbahaya seperti cara-cara merakit bom dan senjata seperti yang terjadi pada remaja Tsamev yang melakukan Bom di Boston tahun $2012^{33}$.

Istilah teror di dunia maya sering dikaitkan dengan kejahatan dan terorisme siber. Sebagai contoh serangan terroris di dunia maya merupakan salah satu kategori kejahatan siber dan dianggap salah satu bentuk penyalahgunaan teknologi untuk keperluan kejahatan. Meskipun istilah "terorisme siber" (cyberterrorism) sering digunakan untuk

${ }^{31}$ Adzkia, A., \& Indra, S. (2015). Kriteria Situs Islam Radikal Versi BNPT.

Retrieved 05 Maret 2016, from CNN Indonesia http://www.cnnindonesia.com/teknologi/20150401093434-185-43429/kriteria-situs-islamradikal-versi-bnpt/

${ }^{32}$ Riyanta, S. (2015). Skenario Kontra-Narasi Radikalisme. Retrieved 15 Maret 2016, from Jurnal Intelijen http://jurnalintelijen.net/2015/12/07/skenario-kontra-narasi$\underline{\text { radikalisme/ }}$

${ }^{33}$ Graham, C. (2013). Terrorism.com: Classifying Online Islamic Radicalism as a Cybercrime. Small Wars Journal, 21(2), 10. 
menggambarkan terorisme di dunia maya, namun tidak berarti terorisme siber tersebut dapat dianggap sebagai bentuk baru kejahatan ${ }^{34}$. Dengan kata lain teror di dunia maya juga memiliki akibat hukum yang sama dan juga akan diperlakukan seperti kejahatan teror yang dilakukan seperti lazimnya.

Namun radikalisme dan terorisme di Internet dapat meyebabkan dampak yang lelbih luas dalam masyarakat karena Internet dapat diakses oleh berbagai masyarakat dimana saja dan kapan saja diseluruh dunia. Seseorang bisa saja menjadi jihadis atau teroris tanpa harus berinteraksi langsung dengan organisasi radikal karena Internet bisa menjadi sarana alternative untuk mempelajari tindakan radikalisme ${ }^{35}$.

Salah satu contoh bagaimana seseorang dapat menjadi radikal hanya dengan berinteraksi lewat internet adalah Hussain Osman yaitu teroris yang mengebom kota London tahun 2004. Dia mengatakan bahwa dia menjadi seorang teroris karena dipengaruhi oleh video - video konflik dan tindakan jihad yang dia tontong di Internet ${ }^{36}$. Contoh dramatis lainnya adalah Khan Al Khalil yang mela kukan pemboman di Kairo tahun 2005 setelah mempelajari cara membuat bom dari situs para jihadis ${ }^{37}$. Fakta inin telah menunjukkan bagaimana Internet telah menjadi

${ }^{34}$ Schjolberg, S. 2005. Terrorism in Cyberspace - Myth or reality? Paper presented at the 4th Annual Conference: Effective Counter-Terrorism and the Rule of International La, Hague, Netherland. http://www.cybercrimelaw.net/documents/Cyberterrorism.pdf , p.2

${ }^{35}$ Ramsay, G, Jihadi Culture, p.3

${ }^{36}$ Awan, A. N, Radicalization on the Internet? The RUSI Journal, vol. 152, No.3, 2007, pp. $76-81$

${ }^{37}$ Sageman, M, Leaderless Jihad. Philadelphia: University of Pennsylvania Press, 2008, p. 125 
Nurdin \& Mohammad Nur Ahsan, Strategi Pencegahan Bahaya...

arena baru bagi kaum radikalis untuk menyebarkan pikiran-pikiran radikal dan juga berbagai tindakan kekerasan dalam masyarakat kita saat ini.

Bukti lain juga menunjukkan betapa bahayanya aktifitas radikalisme di Internet. Hasil berbagai penelitian menunjukkan bahwa Internet sudah menjadi arena baru bagi para radikal untuk melakukan kekerasa. Penemuan terbaru menunjukkan 50\% dari 10 besar jumlah video di media sosial memperlihatkan individu sebagai martyr radikalisme, sementara $30 \%$ lagi memperlihatkan aktifitas bom bunuh diri yang dimanfaatkan untuk mendorong timbulnya kekerasan diantara masyarakat ${ }^{38}$.

b. Bahaya Konten Pornografi di Internet

Seperti yang disebutkan dalam bagian tinjauan pustaka bahwa sebagian besar remaja dengan mudah terpapar terhadap konten pornografi dan radikal di Internet. Bahkan di Indonesia, menurut KPIA, sekitar 92 persen remaja sekolah lanjutan atas telah melakukan akses ke berbagai situs pornografi. Hal terjadi karena pemasangan Internet di berbagai lembaga terutama lembaga pendidikan seperti sekolah-sekolah tidak difasilitasi dengan pengamanan jaringan (filtering). Padahal sekolahsekolah diluar negeri (misalnya di Australia) siswa sekolah hanya dapat mengakses konten pendidikan saja dan sejumlah situs yang telah di filter. Akibat tidak adanya filter maka siswa sekolah dengan mudah dapat

38 Conway, M., \& McInerney, L. (2008). Jihadi Video and Auto-radicalisation: Evidence from an Exploratory YouTube Study. In D. Ortiz-Arroyo, H. Larsen, D. Zeng, D. Hicks \& G. Wagner (Eds.), Intelligence and Security Informatics (Vol. 5376, pp. 108-118): Springer Berlin Heidelberg. 
membuka berbagai situs atau melihat berbagai konten yang tidak layak bagi usia mereka.

Untuk itu diperlukan suatu usaha yang nyata untuk menyadarkan akan bahaya terpaparnya siswa sekolah terhadap situs dan konten porno dan radikal. Proses penyadaran itu perlu diikuti dengan pemeberian ketrampilan untuk memblokir dan menyaring situs-situs dan konten tersebut oleh pihak sekolah. Masalah tersebut bisa di pecahkan melalui kegiatan sosialisasi dan pelatihan untuk memfilter dan memblokir berbabagai situs dan konten yang terkait pornografi dan radikalisme. Program pengabdian ini akan dapat menjadi sarana yang efektif dan nyata dalam pemecahan masalah kurannya pemahaman dan ketrampilan melakukan filttering konten-konten dan situs-situs tersebut.

Dampak pornografi online terhadap remaja sangatlah berat. Menurut hasil penelitian yang dilakukan oleh Owens, dkk pornografi di Internet dapat mempengaruhi daya pikir dan juga fisik remaja ${ }^{39}$. Disamping itu Owens dkk juga menambahkan bahwa remaja yang sering melihat pronografi di Internet juga dapat mempengaruhi perilaku dan kepercayaan mereka terhadap pasangan mereka ketika sudah berumah tangga nanti. Diantaranya timbulnya harapan yang tidak realistis terhadap hubungan suami istri dikemudian hari dan ada kemungkinan melakukan tindakan-tindakan yang tidak diinginkan. Namun yang paling penting dampak jangka pendeknya adalah remaja tersebut kemunkinan besar melakukan tindakan kekerasan seksual terhadap teman-temanya.

Perubahan perilaku tersebut menurut Carter karena terjadi perubahan pada otak dan pikiran remaja setelah menonton pornografi di

${ }^{39}$ Owens, dkk, The Impact of Internet...p, 19-22 
Nurdin \& Mohammad Nur Ahsan, Strategi Pencegahan Bahaya...

Internet ${ }^{40}$. Pengaruh tersebut merubah neuron yang ada dalam otak manusia menjadi tidak alami lagi. Remaja tersebut cenderung menggambarkan kenyataan yang ada seperti apa yang telah di lihat di Internet. Akibatnya jika kenyataan hubungan laki-laki perempuan tidak seperti yang telah dilihat di Internet maka akan berakibat buruk bagi hubungan mereka.

\section{Strategi Pencegahan}

Setelah pada bagian sebelumnya dibahas tentang bahaya yang ditimbulkan oleh konten radikal dan pornografi di Internet, maka galam bagian ini akan dibahas strategy pencegahannya. Ada tiga strategi yang akan dibahas dalam bagian ini yaitu pencegahan melalui dakwah, pencegahan melalui peningkatan peran pemerintah dan aparatnya dalam memonitor secara ketat situs-situs berbahaya tersebut, dan memberikan ketrampilan kepada masyarakat untuk dapat melakukan pemblokiran secara mandiri.

\section{a. Pencegahan Melalui Dakwah}

Agama adalah salah satu instrument yang paling penting dalam mencegah masyarkat untuk mengakses konten-konten radikal dan porno di Internet. Dalam hal ini masyarakat perlu memiliki nilai-nilai agama yang kuat dalam diri mereka untuk membentengi diri dari pengaruh konten radikal dan porno tersebut. Dalam meningkatkan kesadaran berbagai ini, maka tokoh-tokoh agama seperti da'i memegang peranan

${ }^{40}$ Carter, J. (2014). The Effects of Pornography on The Male Brain. Retrieved 15

Maret 2016, from The Ethics \& Religious Liberty Commission http://erlc.com/documents/pdf/20140418_IA_PornMaleBrain.pdf. 
penting. Misalnya para da'i mengajak masyarakat untuk menegakkan nilai-nilai keadilan di tengah-tengah masyarakat, serta mengajak masyrakat untuk mumpas segala bentuk maksiat dan kemungkaran terutama penodaan terhadap agama.

Para da'i dan tokoh agama lainnya berperan dalam menanamkan aqidah yang benar kepada umat terutama generasi muda karena dengan mengajarkan aqidah yang benar segala bahaya didunia maya bisa kita hadapi. Agama Islam memiliki solusi yang sempurna untuk memecahkan segala permasalahan, baik sosial politik maupun sosial keagamaan termasuk hubungan antar umar beragama. Ajaran- ajaran yang ada dalam Islam mengharamkan perbuatan zhalim terhadap sesama manusia bahkan juga terhadap binatang dan lingkungan. Radikalis tidak akan bisa ditumpas hanya dengan kekuatan militer dan senjata saja karena radikalisme juga dalam bentuk gagasan bukan hanya tindakan fisik semata. Dengan kata lain, sekalipun personnya mati, akan tetapi pemikiran dan doktrinnya tetap berkembang melaui tulisan dan mediamedia yang ada di Internet.

Tokoh agama dan para da'i juga perlu mengajar masyarakat untuk mempelajari ilmu agama dari Ulama yang terpercaya dan dalam ilmunya, bukan orang yang berpura-pura menjadi ulama. Dalam hal ini, masyarakat perlu beljar agama dari ahli agama yaitu orang yang menimba ilmu agama dibawah ajaran Ulama, bukan dibawah ajaran orang yang tidak mengerti agama. Misalnya orang mempelajari agama kepada tokoh-tokoh non Muslim atau mempelajari agama secara otodidak secara online melalui situs-situs yang tidak diketahui sumbernya.

Dalam melaksanakan kegiatan dakwah,para da'i sebaiknya mendapat dukungan nyata dari pemerintah untuk menfasilitasi mereka 
Nurdin \& Mohammad Nur Ahsan, Strategi Pencegahan Bahaya...

dalam menyampaikan pesan-pesan agama kepada masyarakat. Terutama para da'i sebaiknya dibekali dengan materi dan kualitas keilmuannya yang baik untuk hadir di tengah-tengah masyarakat yang memiliki paham-paham aneh dan menyimpang. Pemahaman tentang teknologi informasi dan komunikasi juga perlu dimiliki oleh para da'i guna mendukung mereka dalam menyebarkan nilai-nilai agama ditengah masyarakat yang semakin moderen.

b. Pencegahan Melalui Pemblokiran

Berbagai situs radikal dan porno dapat ditangkal dengan melakukan pemblokiran baik oleh pemerintah maupun pihak-pihak lain secar mandiri. Pemblokiran situs-situs dan konten radikal dan pornografi tersebut bisa dilakukan dengan beberapa cara. Pemblokiran tersebut dapat dilakukan dengan menggunakan perangkat lunak (software) atau perangkat keras (hardware). Ada bermacam perangkat lunak yang dapat digunakan untuk memfilter situs-situs dan konten yang dianggap berbaya. Salah satu cara yang paling mudah adalah dengan menggunakan Add Ons yang tersedia pada sejumlah browser misalnya Google Chrome seperti dengan meng-instal MetaSurf Sofware dari Google Chrome tersebut seperti yang dianjurkan oleh Hunter ${ }^{41}$ dan Senkomsidoarjo ${ }^{42}$. Menurut Hunter Surf Watch mampu memblok situs dan konten yang di inginkan sampai dengan 90 persen. Penggunaan software ini karena lebih

${ }^{41}$ Hunter, C. D. (2000). Social Impacts: Internet Filter Effectiveness ŠTesting Over- and Underinclusive Blocking Decisions of Four Popular Web Filters. Social Science Computer Review, 18(2), 214-222

42 Senkomsidoarjo. (2016). Cara Blokir Situs Pornografi Dengan MetaSurf. Retrieved 05 Maret 2016, from SENKOM Mitra Polri Sidoarjo http://www.senkomsidoarjo.org/2015/08/cara-blokir-situs-pornografi-dengan.html 
murah dan mudah didapats secara gratis. software Surf Watch ini juga lazim dimanfaatakan oleh berbagai pihak.

Selanjutnya pemblokiran situs dan konten berbahaya juga bisa dilakukan dengan menggunakan perangkat keras (hardware) seperti WifiRouter $^{43}$. Sistim filtering (penyaringan) dapat dilakukan pada komputer personal (PC), pada local area network (LAN), melalui penyedia layanan Internet, dan mesin pencari seperti Google. Dalam hal ini akses terhadap berbagai situs dan konten di kontrol oleh petugas admin yang ada di tempat. Alat Wifi-Router tersebut banyak tersedia di pasaran dengan harga yang terjangkau.

Dalam pemblokiran online kontent baik menggunakan perangkat lunak maupun perangkat keras, yang di filter bukan hanya teks yang berupa kata tapi juga berupa gambar dan image ${ }^{44}$ misalnya dengan

${ }^{43}$ Kalmar, A., Vida, R., \& Maliosz, M. (2013, 2-5 Dec. 2013). Context-aware addressing in the Internet of Things using Bloom filters. Paper presented at the Cognitive Infocommunications (CogInfoCom), 2013 IEEE 4th International Conference on.

${ }^{44}$ Mofaddel, M. A., \& Sadek, S. (2010, 15-18 Dec. 2010). Adult image content filtering: A statistical method based on Multi-Color Skin Modeling. Paper presented the Signal Processing and Information Technology (ISSPIT), 2010 IEEE International Symposium on. 
Nurdin \& Mohammad Nur Ahsan, Strategi Pencegahan Bahaya...

penggunaan WebGuard ${ }^{45}$ atau pLSA $^{46}$ atau bisa juga filtering dengan menggabungkan image dan texs sekaligus ${ }^{47}$.

c. Peran Negara Melalui Pelarangan

Negara seperti Australia berperan erat dalam pencegahan penyebaran konten pornografi dan radikal. Terkait pornografi, meskipun mereka tidak melarang pergaulan bebas, namun mereka sangat melindungi anak-anak dibawah umur terhadap konten pornografi. Misalnmya di sekolah-sekolah akses terhadap internet hanya bisa dipakai untuk mengakses materi sekolah saja. Sementara dinegara kita saluran internet yang ada disekolah-sekolah terbuka untuk mengakses apa saja. Dalam hal ini peran pemerintah pada berbagai level sangat diperlukan untuk menangkal konten radikal dan porno tersebut. Salah satu peran pemerintah yang telah dimainkan dengan nyata dalam pemberantasan radikalisme dan pornograi online adalah dengan terlibat secara akti Kementerian Kominfo melalui PT Telkom untuk memblokir berbagai situssitud porno dan radikal.

Kemudian pemerintah juga perlu mengawasi secara ketat seluruh situs online yang ada. Startegi ini bukan untuk mengekang kemunculan

\footnotetext{
${ }^{45}$ Hammami, M., Chahir, Y., \& Chen, L. (2003, 13-17 Oct. 2003). WebGuard: Web based adult content detection and filtering system. Paper presented at the Web Intelligence, 2003. WI 2003. Proceedings. IEEE/WIC International Conference on.

${ }^{46}$ Lienhart, R., \& Hauke, R. (2009, June 28 2009-July 3 2009). Filtering adult image content with topic models. Paper presented at the Multimedia and Expo, 2009. ICME 2009. IEEE International Conference on.

${ }^{47}$ Hammami, M., Chahir, Y., \& Chen, L. (2006). WebGuard: a Web filtering engine combining textual, structural, and visual content-based analysis
} 
situs-situs online, tapi ini sebagai upaya membentengi masyarakat dari keterpaparan terhadap berbagai konten radikal dan pornografi. Bila pornografi dan radikalisme itu menyebabkan banyak mudharat, maka jalan yang menuju ke kedua hal itu pun perlu diawasi dengan ketat. Dalam hal ini negara memiliki peran vital untuk mencegah munculnya situs-situs semacam itu.

Disamping pelarangan, pemerintah juga mengarahkan dan bertanggung jawab penuh membina dan mendidik masyarakat sehingga masyarakat mempunyai visi dan pandangan hidup yang positif kedepan, terutama bagaimana meraih kebahagiaan di dunia dan diakhirat dengan menjaukan dirinya dari konten-konten terlarang. Ketika adanya pandangan yang positif dari masyarakat maka mereka akan menjauhkan dirinya dari mengakses konten-konten radikal dan porno.

Namun peran pemerintah saja dalam melakukn pemblokiran dan pelarangan terhadap situs-situs porno dan radikal belum cukup karena pemerintah melalui Depkominfo melakukan pemblokiran secara berkala pada periode waktu tertentu saja. Sementara situs-situs pordo dan radikal terus muncul dan melakukan perubahan alamat situs setiap hari. Untuk itu pemerintah perlu melatih masyarakat terutama instansi-instansi dibawah seperti sekolah-sekolah dan lainnya untuk dapat melakukan pemblokiran secara mandiri setiap saat. Dengan adanya ketrampilan untuk melakukan pemblokiran secara mandiri maka berbagai situs prono dan radikal dapat diblok setiap saat tanpa harus menunggu pemblokiran yang dilakukan oleh Depkominfo.

\section{Kesimpulan}


Nurdin \& Mohammad Nur Ahsan, Strategi Pencegahan Bahaya...

Kesimpulan dari tulisan ini adalah bahwa konten-konten radikal dan porno yang ada di Internet membawa bahaya yang luar biasa bagi kehidupan masyarakat. Konten radikal dapat menyebabkan masyakarat memiliki pandangan yang sempit dan dapat menyebabkan masyarakat tidak toleran terhadap masyarakat lainnya. Akibatnya mereka akan melakukan tindakan-tindakan yang menyebabkan terjadinya kerusakan di tengah masyarakat baik berupa kerusakan fisik maupun non fisik. Sementara itu, konten pornografi di Internet juga menyebabkan bahaya bagi perilaku kehidupan manusia seperi melakukan kekerasan seksual pasangannya sendiri maupun terhadap orang lain seperti pemerkosaan.

Untuk mencegah bahaya yang ditimbulkan oleh konten-konten radikal dan porno yang ada di dunia maya, maka perlu dilakukan pencegahan yang antara lain dapat dilakukan dengan cara peningkatan aktifitas dakwah ditengah-tengah masyarakat, melakukan pemblokiran terhadap situs-situs yang mempublikasikan konten radikal dan porno baik yang dilakukan oleh pemerintahn maupun secara mandiri oleh masyarakat, dan yang terakhir yaitu dengan meninmgkatkan peran pemrintah untuk melakukan pemblokiran dan pengawasan terhadap situssitus tersebut.

\section{Daftar Pustaka}

Adzkia, A., \& Indra, S. (2015). Kriteria Situs Islam Radikal Versi BNPT. Retrieved 05 Maret 2016, from CNN Indonesia http://www.cnnindonesia.com/teknologi/20150401093434-18543429/kriteria-situs-islam-radikal-versi-bnpt/

APJII. (2014). Profil Pengguna Internet Indonesia 2014. Jakarta: Asosiasi Penyedia Jasa Internet Indonesia (APJII). 
Bappeda-Provinsi-Sulteng. (2015). Bupati Protes Disebut Daerah Miskin Kedua di Sulteng. Retrieved 06 Maret 2015, from Radar Sulteng http://www.radarsulteng.co.id/index.php/berita/detail/rubrik/49/712 $\underline{4}$

Carter, J. (2014). The Effects of Pornography on The Male Brain. Retrieved 15 Maret 2016, from The Ethics \& Religious Liberty Commission http://erlc.com/documents/pdf/20140418_IA_PornMaleBrain.pdf.

Conway, M., \& McInerney, L. (2008). Jihadi Video and Autoradicalisation: Evidence from an Exploratory YouTube Study. In D. Ortiz-Arroyo, H. Larsen, D. Zeng, D. Hicks \& G. Wagner (Eds.), Intelligence and Security Informatics (Vol. 5376, pp. 108-118): Springer Berlin Heidelberg.

Graham, C. (2013). Terrorism.com: Classifying Online Islamic Radicalism as a Cybercrime. Small Wars Journal, 21(2), 10.

Hammami, M., Chahir, Y., \& Chen, L. (2003, 13-17 Oct. 2003). WebGuard: Web based adult content detection and filtering system. Paper presented at the Web Intelligence, 2003. WI 2003. Proceedings. IEEE/WIC International Conference on.

Hammami, M., Chahir, Y., \& Chen, L. (2006). WebGuard: a Web filtering engine combining textual, structural, and visual content-based analysis

Hunter, C. D. (2000). Social Impacts: Internet Filter EffectivenessŠTesting Over- and Underinclusive Blocking Decisions of Four Popular Web Filters. Social Science Computer Review, 18(2), 214-222. doi: $10.1177 / 089443930001800209$ 
Nurdin \& Mohammad Nur Ahsan, Strategi Pencegahan Bahaya...

InternetWorldStats. (2015). Internet Users in Asia. Retrieved 20 januari 2016, from Internet World Stats http://www.internetworldstats.com/stats3.htm\#asia

Kalmar, A., Vida, R., \& Maliosz, M. (2013, $2-5$ Dec. 2013). Context-aware addressing in the Internet of Things using Bloom filters. Paper presented at the Cognitive Infocommunications (CogInfoCom), 2013 IEEE 4th International Conference on.

Kandepag. (2015). Data Madrasah di Kabupaten Poso Poso: Kantor Departemen Agama Kabupaten Poso.

KBI. (Ed.) (1999). Jakarta: Balai Pustaka.

Kominfo. (2014). Siaran Pers Tentang Riset Kominfo dan UNICEF Mengenai Perilaku Anak dan Remaja Dalam Menggunakan Internet Retrieved 03 Maret 2016, from Kominfo http://kominfo.go.id/index.php/content/detail/3834/Siaran+Pers + No. +17-PIH-KOMINFO-2-

Kominfo. (2015). Kominfo Sudah Blokir 814.594 Situs Radikal Retrieved 21 Pebruari 2016, from Kominfo http://kominfo.go.id/index.php/content/detail/5083/Kominfo +Suda $\mathrm{h}+$ Blokir $+814.594+$ Situs + Radikal

KPAI. (2014). Survei: 97\% Remaja Indonesia Mengakses Situs Porno. Retrieved 03 Maret 2016, from Okezone http://techno.okezone.com/read/2013/09/24/55/870832/survei-97remaja-indonesia-mengakses-situs-porno

Lienhart, R., \& Hauke, R. (2009, June 28 2009-July 3 2009). Filtering adult image content with topic models. Paper presented at the Multimedia and Expo, 2009. ICME 2009. IEEE International Conference on. 
Malamuth, N. M. (1999). Pornography Encyclopedia of Violence, Peace, and Conflict, Volume (Vol. 3, pp. 14). Los Angeles.

Mauro, R. (2014). Understanding Islamic Extremism. Retrieved 24 June 2015, from The Clarion Project http://www.clarionproject.org/understanding-islamism/islamicextremism\#

Mofaddel, M. A., \& Sadek, S. (2010, 15-18 Dec. 2010). Adult image content filtering: A statistical method based on Multi-Color Skin Modeling. Paper presented at the Signal Processing and Information Technology (ISSPIT), 2010 IEEE International Symposium on.

National-Coalition. (2011). FACTS FOR PREVENTION: The Impact of Pornography on Children \& Youth. Retrieved 05 Maret 2016, from National Coalition to Prevent http://www.preventtogether.org/Resources/Documents/Impact_of Porn on Youth_9.pdf.

Nurdin, N. (2016). Radicalism on Worl Wide Web and Propaganda Strategy Al-Ulum, 16(2).

Owens, E. W., Behun, R. J., Manning, J. C., \& Reid, R. C. (2012). The Impact of Internet Pornography on Adolescents: A Review of the Research. Sexual Addiction \& Compulsivity, 19, 99-122.

Rea, M. C. (2001). What is pornography? Malden, USA: Blackwell Publisher, Inc.

Riyanta, S. (2015). Skenario Kontra-Narasi Radikalisme. Retrieved 15 Maret 2016, from Jurnal Intelijen http://jurnalintelijen.net/2015/12/07/skenario-kontra-narasiradikalisme/ 
Nurdin \& Mohammad Nur Ahsan, Strategi Pencegahan Bahaya...

Saifuddin, L. H. (2016). Menag: Situs Radikal di Indonesia Berkembang Pesat. Retrieved 3 Maret 2016, from Solopos

Senkomsidoarjo. (2016). Cara Blokir Situs Pornografi Dengan MetaSurf. Retrieved 05 Maret 2016, from SENKOM Mitra Polri Sidoarjo http://www.senkomsidoarjo.org/2015/08/cara-blokir-situspornografi-dengan.html

Wicaksono, K., \& Haryanto, A. T. (2016). Ratusan Ribu Situs Diblokir Sepanjang 2015. Retrieved 03 Maret 2016, from VIVA http://teknologi.news.viva.co.id/news/read/718117-ratusan-ribusitus-diblokir

Zulkifli Taher. (2015). Radikalisme Berbasis Agama di Sulteng, Kelompok Santoso Masih Jadi Ancaman Retrieved 05 Maret 2016, from Kementerian Agama RI http://bimasislam.kemenag.go.id/post/berita/radikalisme-berbasisagama-di-sulteng-kelompok-santoso-masih-jadi-ancaman- 